\title{
Hybrid Cascaded H-Bridge Multilevel-Inverter Induction-Motor-Drive Direct Torque Control for Automotive Applications
}

\author{
Farid Khoucha, Soumia Mouna Lagoun, Khoudir Marouani, Abdelaziz Kheloui, and \\ Mohamed El Hachemi Benbouzid, Senior Member, IEEE
}

\begin{abstract}
This paper presents a hybrid cascaded H-bridge multilevel motor drive direct torque control (DTC) scheme for electric vehicles (EVs) or hybrid EVs. The control method is based on DTC operating principles. The stator voltage vector reference is computed from the stator flux and torque errors imposed by the flux and torque controllers. This voltage reference is then generated using a hybrid cascaded $\mathrm{H}$-bridge multilevel inverter, where each phase of the inverter can be implemented using a dc source, which would be available from fuel cells, batteries, or ultracapacitors. This inverter provides nearly sinusoidal voltages with very low distortion, even without filtering, using fewer switching devices. In addition, the multilevel inverter can generate a high and fixed switching frequency output voltage with fewer switching losses, since only the small power cells of the inverter operate at a high switching rate. Therefore, a high performance and also efficient torque and flux controllers are obtained, enabling a DTC solution for multilevel-inverter-powered motor drives.
\end{abstract}

Index Terms-Automotive application, direct torque control (DTC), induction motor, multilevel inverters.

\section{INTRODUCTION}

$\mathbf{M}$ ULTILEVEL voltage-source inverter topologies, including diode-clamped, flying capacitor, and cascaded H-bridge structures, are intensively studied for high-power applications [1]-[5], and standard drives for medium-voltage industrial applications have become available [6], [7]. Solutions with a higher number of output voltage levels have the ability to synthesize waveforms with a better harmonic spectrum and to limit the motor-winding insulation stress. However, their increasing number of devices tends to reduce the overall reliability and efficiency of the power converter.

Manuscript received December 17, 2008; revised November 12, 2009. First published December 4, 2009; current version published February 10, 2010.

F. Khoucha is with the Laboratoire Brestois de Mécanique et des Systèmes (EA 4325), University of Brest, 29238 Brest, France, and also with the Electrical Engineering Department, Polytechnic Military Academy, Algiers 16111, Algeria (e-mail: fkhoucha04@yahoo.fr).

S. M. Lagoun is with the Laboratoire Brestois de Mécanique et des Systèmes (EA 4325), University of Brest, 29238 Brest, France, and also with the University of Laghouat, Laghouat 03000, Algeria (e-mail: lagoun_mona@yahoo.fr).

K. Marouani and A. Kheloui are with the Electrical Engineering Department, Polytechnic Military Academy, Algiers 16111, Algeria (e-mail: marouani_ khoudir@yahoo.fr; akheloui@caramail.com).

M. E. H. Benbouzid is with the Laboratoire Brestois de Mécanique et des Systèmes (EA 4325), University of Brest, 29238 Brest, France (e-mail: m.benbouzid@ieee.org).

Color versions of one or more of the figures in this paper are available online at http://ieeexplore.iee.org.

Digital Object Identifier 10.1109/TIE.2009.2037105
On the other hand, solutions with a low number of levels either need a rather large and expensive $L C$ output filter to limit the motor-winding insulation stress or can only be used with motors that do withstand such stress.

Most investigations concerned topologies with the same voltage rating for all devices. The advantages of such symmetric multilevel converters are modularity and control simplicity. Hybrid multilevel inverters use different types of voltage sources in various parts of the inverter. These sources, which can be batteries, ultracapacitors, or fuel cell, allow this structure to be narrowly well adapted to electric vehicles (EVs) and hybrid EVs (HEVs) [8]-[11]. By addition and subtraction of these voltages, more different output voltage levels can be generated with the same number of components, compared to a symmetric multilevel inverter [12]-[17]. Higher output quality can be obtained with fewer cascaded cells and control complexity, and output filters can be remarkably shrunk or even eliminated.

One of the methods that have been used by one major manufacturer in multilevel inverters is direct torque control (DTC), which is recognized today as a high-performance control strategy for ac drives [18]-[24]. Several authors have addressed the problem of improving the behavior of DTC ac motors, particularly by reducing the torque ripple. Different approaches have been proposed [12]: improving the lookup table; varying the hysteresis bandwidth of the torque controller; and using flux, torque, and speed observers. Although these approaches are well suitable for the classical two-level inverter, their extension to a greater number of levels is not easy. Throughout this paper, a theoretical background is used to design a simple and practical strategy that is compatible with hybrid cascaded $\mathrm{H}$ bridge multilevel inverter [25]. It allows not only controlling the electromagnetic state of the motor with improved performance (minimization of the torque ripple) but also reducing flux and current distortion caused by flux position sector change. An induction motor has been adopted for the vehicle propulsion because it seems to be the candidate that better fulfills the major requirements for EV or HEV electric propulsion [26].

\section{CASCADEd H-BRidge Structure ANd Operation}

The hybrid cascaded H-bridge inverter power circuit is shown in Fig. 1. The inverter is composed of three legs, in each one is a series connection of two H-bridge inverters fed by independent dc sources that are not equal $\left(V_{1}<V_{2}\right)$. 


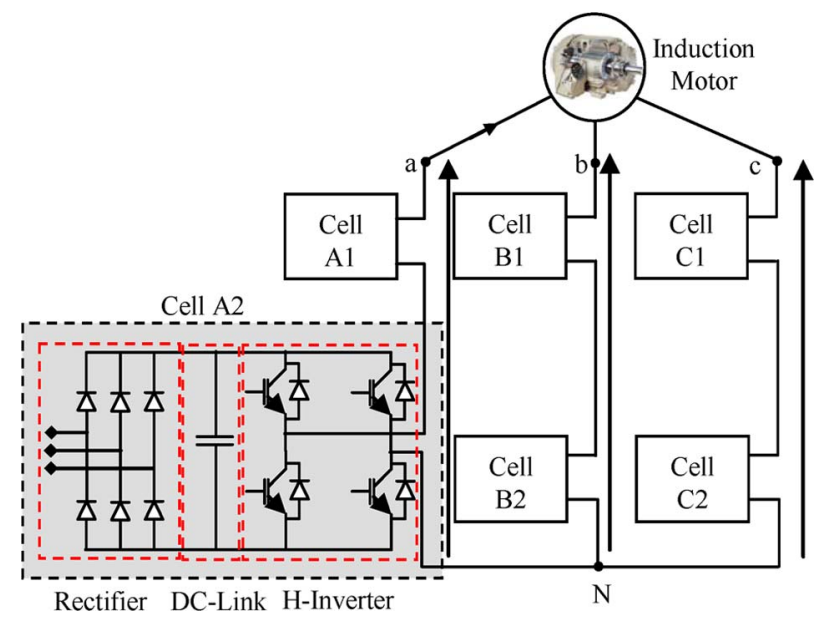

Fig. 1. Asymmetric cascaded H-bridge multilevel inverter.

Indeed, it may be obtained from batteries, fuel cells, or ultracapacitors in EVs or HEVs [11], [27], [28].

The use of asymmetric input voltages (inverter fed by a set of dc-voltage sources where at least one of them is different from the other one) can reduce, or when properly chosen, eliminate redundant output levels, maximizing the number of different levels generated by the inverter. Therefore, this topology can achieve the same output voltage quality with fewer number of semiconductors [13].

The maximum number of redundancies is equal to $\left(3^{K}-\right.$ $2 K-1)$ and can be obtained when the partial dc voltages are equal to $E /(N-1)$. If there is $K$ connected cells per multilevel-inverter phase leg, $3^{K}$ switching configurations are possible. The multilevel-inverter output voltage depends on the partial voltage feeding each partial cell. The possible number of redundant switching states can be reduced if the cells are fed by unequal dc-voltage sources. This also reduces volume and costs and offers inherent low switching losses and high conversion efficiency [29]. When cascading two-level inverters like H-bridges, the optimal asymmetry is obtained by using voltage sources proportionally scaled to the two- or threeH-bridge power.

Particular cell $i$ can generate three levels $\left(+V_{i}, 0,-V_{i}\right)$. The total inverter output voltage for a particular phase $j$ is defined by

$$
\nu_{j N}=\sum_{i=1}^{m} \nu_{j i}=\sum_{i=1}^{m} V_{i}\left(S_{i 1}-S_{i 2}\right), \quad j \in\{a, b, c\}
$$

where $\nu_{i j}$ is the $i$ cell output voltage, $m$ is the number of cells per phase, and $\left(S_{i 1}, S_{i 2}\right)$ is the switching state associated to the $i$ cell. Equation (1) explicitly shows how the output voltage of one cell is defined by one of the four binary combinations of switching state, with " 1 " and " 0 " representing the "ON" and "OFF" states of the corresponding switch, respectively.

The optimal asymmetry is obtained with dc links scaled in powers of two or three, generating seven (Fig. 2) or nine (Fig. 3) different output levels. Nine different output levels can be generated using only two cells (eight switches), while four cells (16 switches) are necessary to achieve the same amount of level with a symmetric-fed inverter.
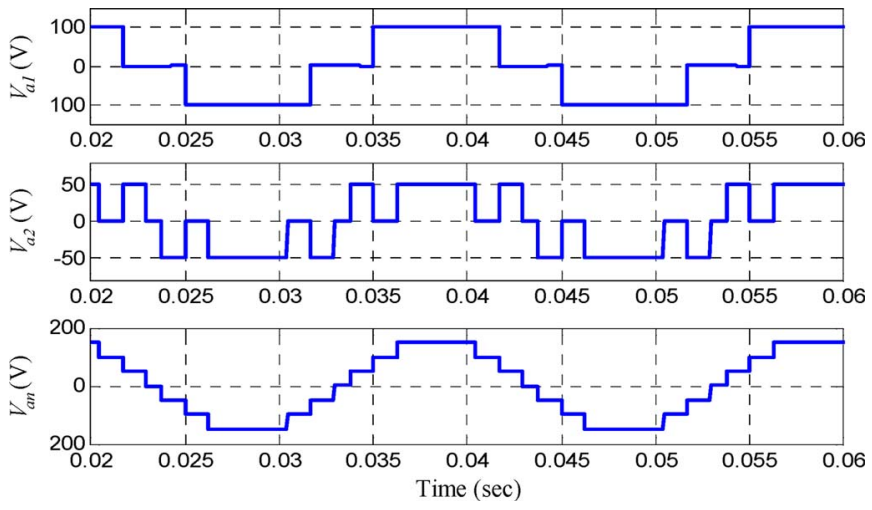

Fig. 2. Asymmetric multilevel inverter with seven-level output voltage synthesis.
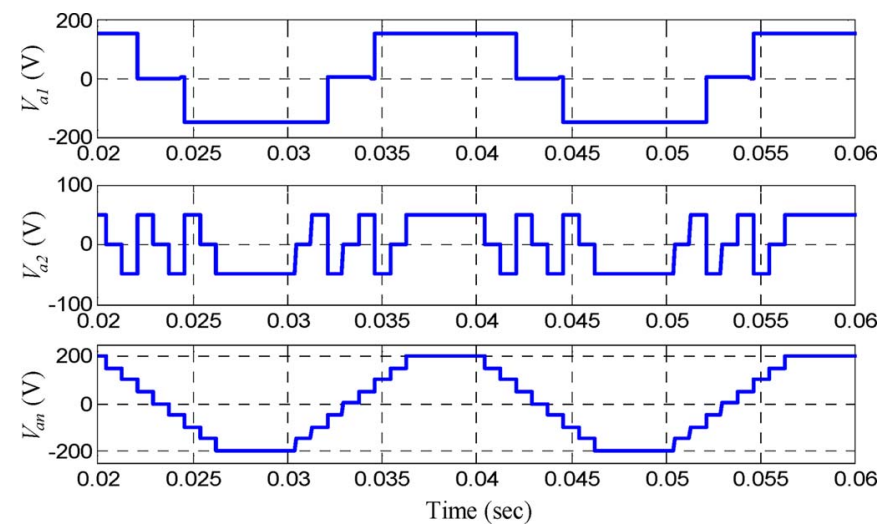

Fig. 3. Asymmetric multilevel inverter with nine-level output voltage synthesis.

\section{INDUCTION MOTOR DTC}

DTC is an alternative method to flux-oriented control. The basic principle is the selection of the electromagnetic torque and stator flux references by choosing the appropriate inverter state [30]. Several advantages may be considered, namely, nearly sinusoidal stator flux and current waveforms, higher robustness regarding motor parameter variations except the stator winding resistance, higher torque dynamics, and easier flux and speed estimator implementation, since coordinate transformation is not required. However, in the standard version, important torque ripple and high switching losses are obtained due to the use of hysteresis bands and the small number of applicable voltage vectors. Moreover, the converter switching frequency is inherently variable and very dependent on the torque and shaft speed. This produces torque harmonics with variable frequencies and acoustic noise with disturbance intensities that are very dependent on these mechanical variables and particularly grating at low speed [18], [31].

The additional degrees of freedom (space vectors, phase configurations, etc.) provided by the multilevel inverter should therefore be exploited by the control strategy in order to reduce the previously cited drawbacks.

\section{A. Nomenclature}

$\nu_{s}\left(i_{s}\right) \quad$ Stator voltage (current) vector.

$\phi_{s}\left(\phi_{r}\right)$ Stator (rotor) flux vector. 


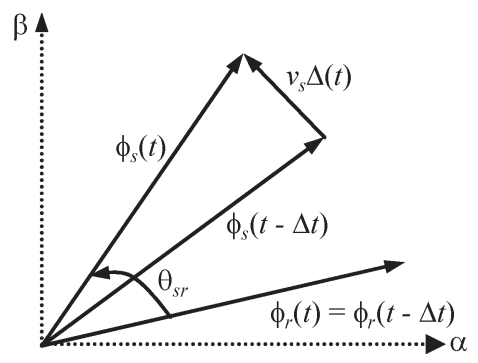

Fig. 4. Influence of $\nu_{s}$ over $\phi_{s}$ during a simple interval $\Delta t$.

$T_{e} \quad$ Electromagnetic torque.

$R_{s} \quad$ Stator resistance.

$L_{s}\left(L_{r}\right) \quad$ Stator (rotor) inductance.

$L_{m} \quad$ Magnetizing inductance.

$\sigma \quad$ Total leakage coefficient, $=1-L_{m}^{2} / L_{s} L_{r}$.

$\theta_{s r} \quad$ Angle between stator and rotor flux vectors.

$p \quad$ Pole pair number.

\section{B. Torque and Flux Estimation}

The stator flux vector of an induction motor is related to the stator voltage and current vectors by

$$
\frac{d \phi_{s}(t)}{d t}=\nu_{s}(t)-R_{s} i_{s}(t) .
$$

Maintaining $\nu_{s}$ constant over a sample time interval and neglecting the stator resistance, the integration of (2) yields

$$
\Delta \phi_{s}(t)=\phi_{s}(t)-\phi_{s}(t-\Delta t)=\int_{t-\Delta t}^{t} \nu_{s} \Delta t .
$$

Equation (3) reveals that the stator flux vector is directly affected by variations on the stator voltage vector. On the contrary, the influence of $\nu_{s}$ over the rotor flux is filtered by the rotor and stator leakage inductances [30] and is therefore not relevant over a short-time horizon. Since the stator flux can be changed quickly while the rotor flux rotates slower, the angle between both vectors $\theta_{s r}$ can be controlled directly by $\nu_{s}$. A graphical representation of the stator and rotor flux dynamic behaviors is shown in Fig. 4. The exact relationship between the stator and rotor fluxes shows that keeping the amplitude of $\phi_{s}$ constant will produce a constant flux $\phi_{r}$ [6].

Since the electromagnetic torque developed by an induction motor can be expressed by [6]

$$
T_{e}=\frac{3}{2} p \frac{L_{m}}{\sigma L_{s} L_{r}} \phi_{s} \phi_{r} \sin \theta_{s r}
$$

It follows that a change in $\theta_{s r}$ due to the action of $\nu_{s}$ allows for direct and fast change in the developed torque.

DTC uses this principle to achieve the induction motor desired torque response by applying the appropriate stator voltage vector to correct the flux trajectory.

\section{Voltage Vector Selection}

Fig. 5 shows one of the 343 voltage vectors generated by the inverter at instant $t=k$, denoted by $\nu_{s}^{k}$ (central dot). The

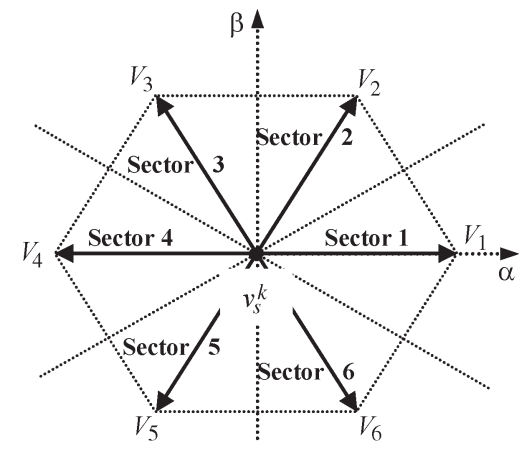

Fig. 5. Possible voltage changes $\Delta \nu_{s}^{k}$ that can be applied from certain $\nu_{s}^{k}$.

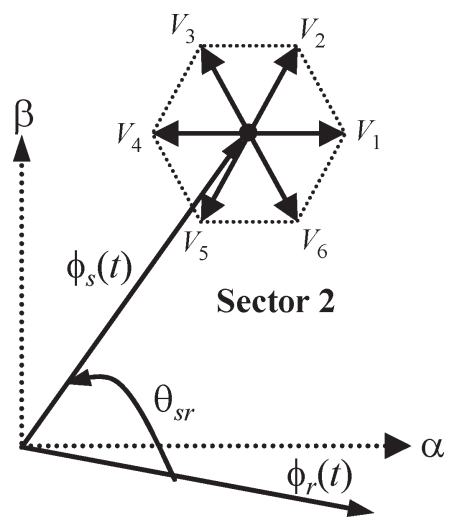

Fig. 6. Voltage selection $\Delta \nu_{s}^{k}$ in sector 2.

next voltage vector to be applied to the load $\nu_{s}^{k+1}$ can be expressed by

$$
\nu_{s}^{k+1}=\nu_{s}^{k}+\Delta \nu_{s}^{k}
$$

where $\Delta \nu_{s}^{k}=\left\{\nu_{i} \mid i=1, \ldots, 6\right\}$. Each vector $\nu_{i}$ corresponds to one corner of the elemental hexagon illustrated in gray and by the dashed line in Fig. 5. The task is to determine which $\nu_{s}^{k+1}$ will correct the torque and flux responses, knowing the actual voltage vector $\nu_{s}^{k}$, the torque and flux errors $e_{\phi}^{k}$ and $e_{T}^{k}$, and the stator flux vector position (sector determined by $\theta_{s}$ ), except if the voltage vector is in the end of the external hexagon. In this case, a trajectory correction is necessary because the voltage vector that should be chosen by the algorithm cannot be achieved by the inverter (this will be clearly shown in Fig. 8). Note that the next voltage vector $\nu_{s}^{k+1}$ applied to the load will always be one of the six closest vectors to the previous $\nu_{s}^{k}$; this will soften the actuation effort and reduce the high dynamics in torque response due to possible large changes in the reference.

Using (4) and (5) and analyzing, for example, sector 2 shown in Fig. 6, the application of $\nu_{1}$ increases the stator flux amplitude but reduces $\theta_{s r}$, leading to a torque reduction. Conversely, $\nu_{4}$ reduces the flux magnitude, while it increases $\theta_{s r}$ and, thus, the torque. If $\nu_{3}$ is applied to the load, both torque and flux increase, and it is clear that $\nu_{6}$ produces the inverse effect. Table I summarizes the vector selections according to the aforementioned criterion for the different sectors and comparator outputs (desired $\phi_{s}$ and $T_{e}$ corrections).

To implement the DTC of the induction motor fed by a hybrid H-bridge multilevel inverter, one should determine at each sampling period the logic state of the inverter switches 
TABLE I

Voltage Vector Selection Lookup TABle

\begin{tabular}{|c|c|c|c|c|}
\hline \multirow{2}{*}{ Sector } & \multicolumn{4}{|c|}{$\operatorname{sign}\left(e_{\phi}{ }^{k}, e_{T}{ }^{k}\right)$} \\
\cline { 2 - 5 } & $(+,+)$ & $(+,-)$ & $(-,+)$ & $(-,-)$ \\
\hline 1 & $V_{2}$ & $V_{6}$ & $V_{3}$ & $V_{5}$ \\
\hline 2 & $V_{3}$ & $V_{1}$ & $V_{4}$ & $V_{6}$ \\
\hline 3 & $V_{4}$ & $V_{2}$ & $V_{5}$ & $V_{1}$ \\
\hline 4 & $V_{5}$ & $V_{3}$ & $V_{6}$ & $V_{2}$ \\
\hline 5 & $V_{6}$ & $V_{4}$ & $V_{1}$ & $V_{3}$ \\
\hline 6 & $V_{1}$ & $V_{5}$ & $V_{2}$ & $V_{4}$ \\
\hline
\end{tabular}

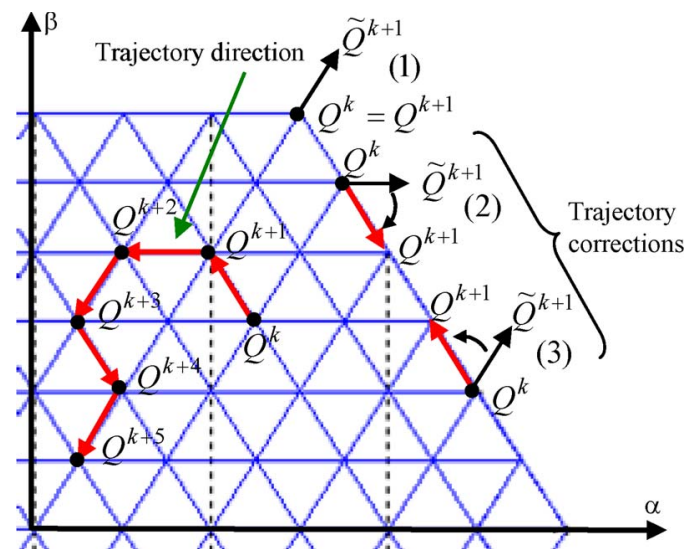

Fig. 7. Optimal space vector tracking and trajectory correction in the stationary $\alpha \beta$ frame.

as a function of instantaneous values of torque and flux for the selection of the space vector in the $\alpha-\beta$ frame.

The proposed control algorithm was divided into two major tasks which are independent and executed in cascade.

The first task aims at the control of the electromagnetic state of the machine. The instantaneous values of torque, flux, and their variations will be taken into account for the selection of the space vector in the $\alpha-\beta$ plane. Once the space is chosen, the sequence of phase levels can be selected. To ensure this task, one should detect the position of the space vector in the $\alpha-\beta$ frame $\left(Q^{k}\right.$ at sampling time $\left.t^{k}\right)$. The proposed algorithm must then select the next position $Q^{k+1}$ to be achieved before the next sampling instant $t^{k+1}$ (Fig. 7) in order to reduce voltage step magnitude. Only one step displacement in the $\alpha-\beta$ frame is authorized per sampling period $T_{s}$. Hence, in the absence of inverter saturation, $Q^{k+1}$ must coincide with one of the six corners of the elementary hexagon centered at $Q^{k}$. The same procedure will be carried out at the next period in order to determine the next trajectory direction, yielding $Q^{k+2}$, which, in turn, will coincide with one of the six corners of the new elementary hexagon centered at $Q^{k+1}$.

The second task exploits the degree of freedom related to the multilevel topology to choose the sequence of phase levels that synthesizes the voltage vector that was selected previously. There are several sequences of phase levels that are able to generate the same vector shown in Fig. 8; this degree of freedom can therefore be exploited to reduce the voltage step magnitude

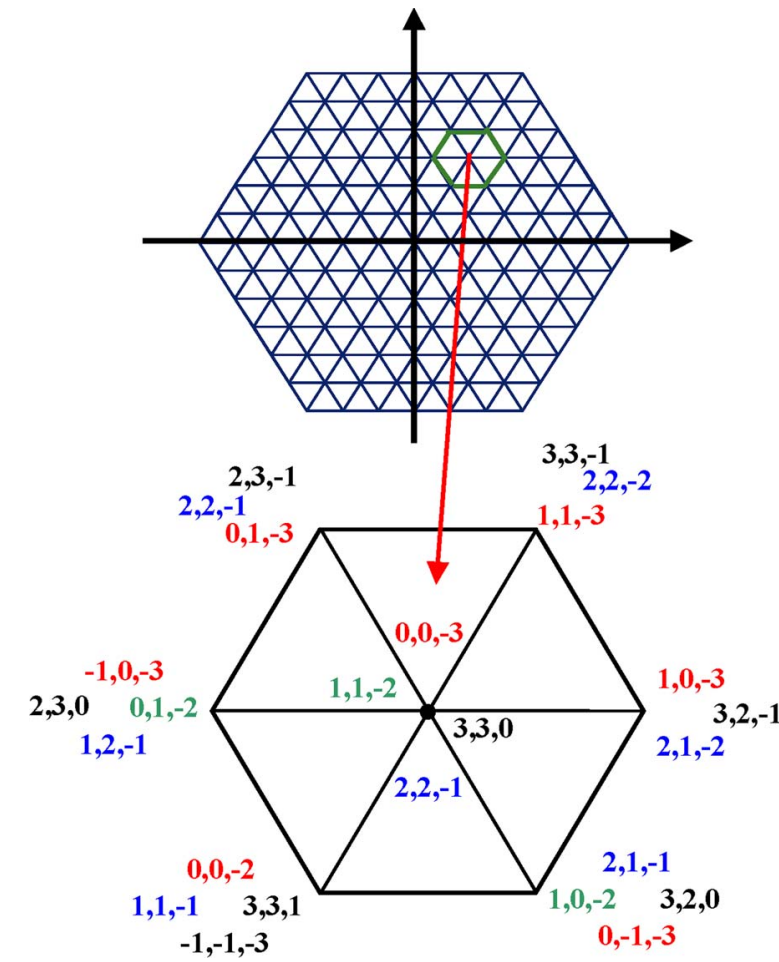

Fig. 8. Space vector and sequences of a seven-level cascaded H-bridge inverter.

according to one of the following criteria: 1) minimize the commutation number per period; 2) distribute commutations for the three phases per period; or 3 ) choose a vector which minimizes the homopolar voltage. This task allows losses and torque ripple minimization. Finally, the configuration of each phase will be selected and must be able to generate the phase levels.

In the case of inverter saturation, which happens if $Q^{k}$ gives an unreachable point for $Q^{k+1}$, a trajectory correction is necessary. Fig. 7 shows the three cases which lead to an unreachable point. In cases 2) and 3), the closest displacement direction is selected. Case 1) illustrates a particular situation in which no switching should be performed since the nearest reachable trajectory goes roughly toward the opposite sense of the favored one given by the lookup table (Table I).

\section{Simulation Results}

For the validation of the previously discussed control approach, simulations on a seven-level inverter-fed induction motor have been carried out using Matlab-Simulink. The simulated induction motor ratings are given in the Appendix.

Figs. 9-14 show the simulation results for torque, flux, currents, voltages, and the corresponding fast Fourier transform (FFT) spectrums, when the square torque reference waveform of Fig. 9 is applied.

When analyzing the simulation results, the following conclusions are drawn.

1) Torque pulsations are reduced compared to a twoand five-level inverter DTC strategy, as shown in Figs. 15 and 16.

2) DTC also controls the stator flux that is shown in Fig. 10. With this strategy, it has been possible to improve the flux 


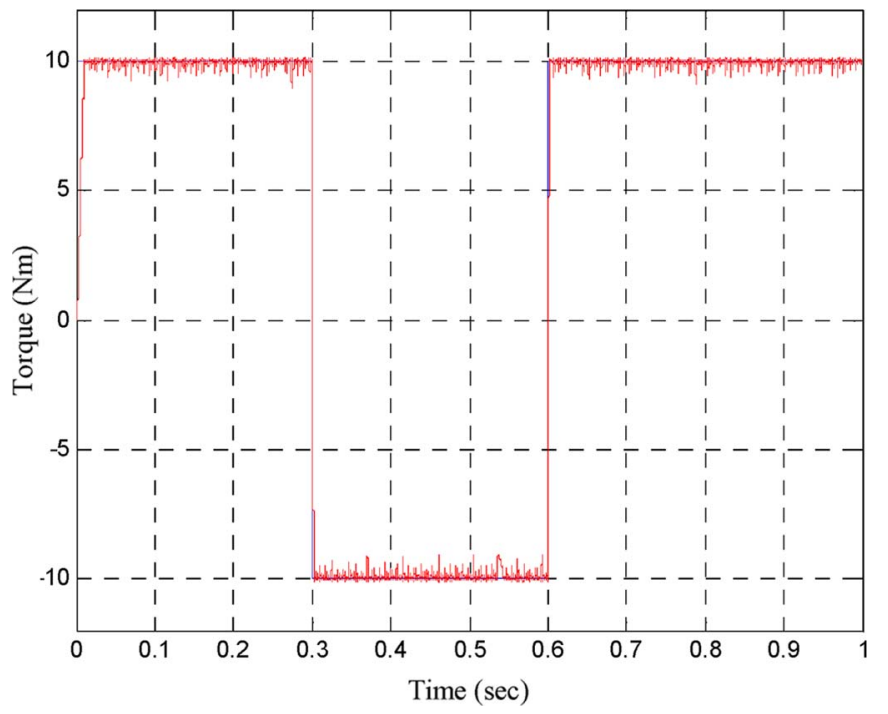

Fig. 9. Seven-level cascaded H-bridge inverter estimated torque waveform.

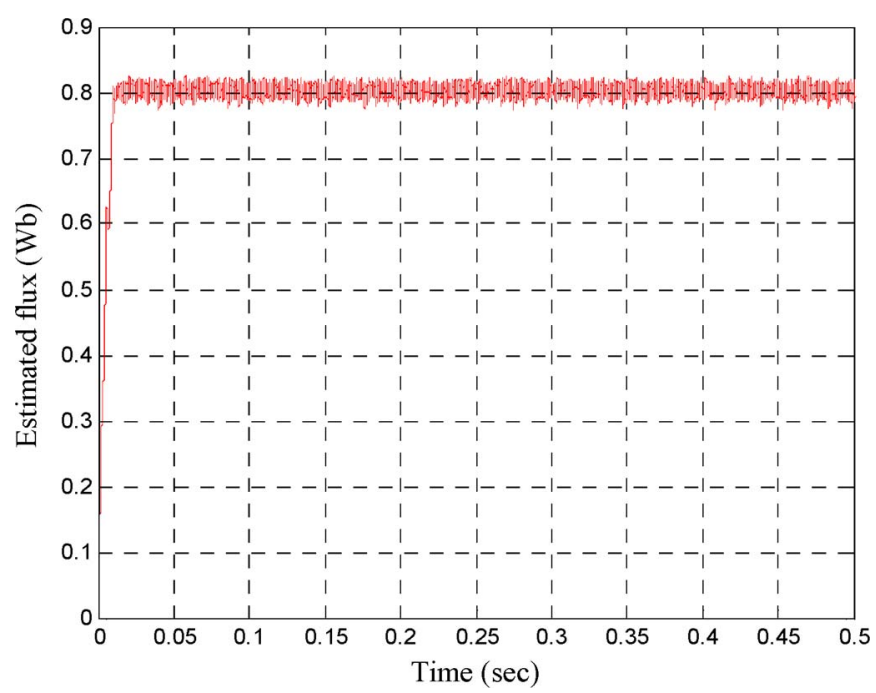

Fig. 10. Seven-level cascaded H-bridge inverter stator flux waveform.

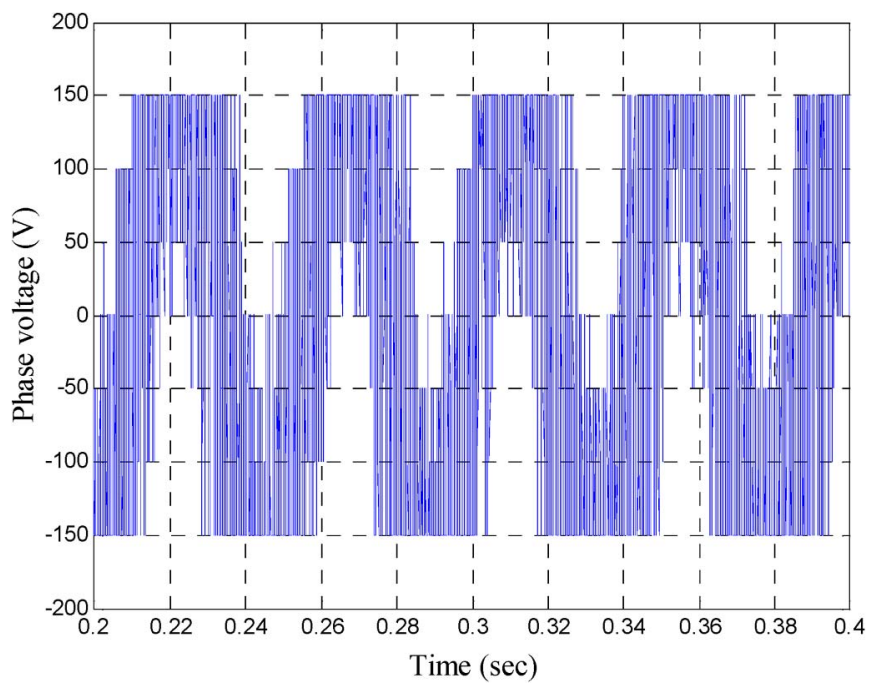

Fig. 11. Seven-level cascaded H-bridge inverter phase voltage waveform.

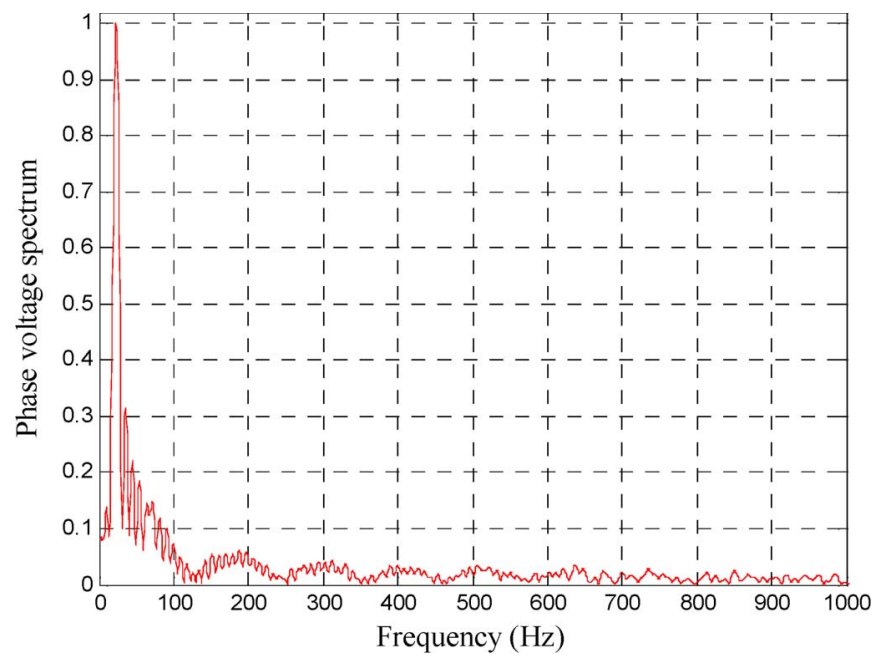

Fig. 12. Seven-level cascaded H-bridge inverter phase voltage FFT analysis.

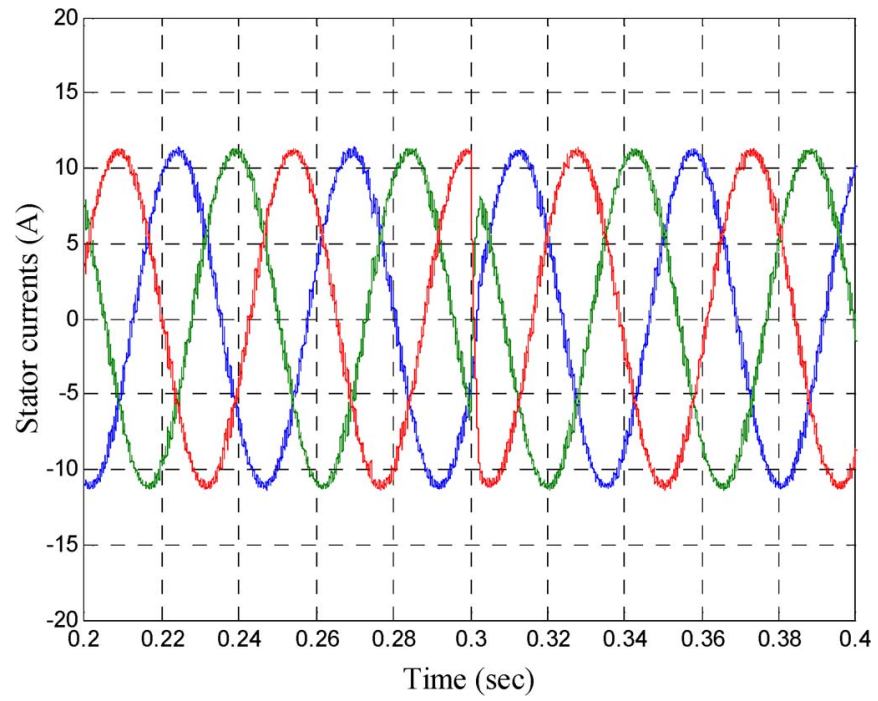

Fig. 13. Seven-level cascaded H-bridge inverter output current waveform.

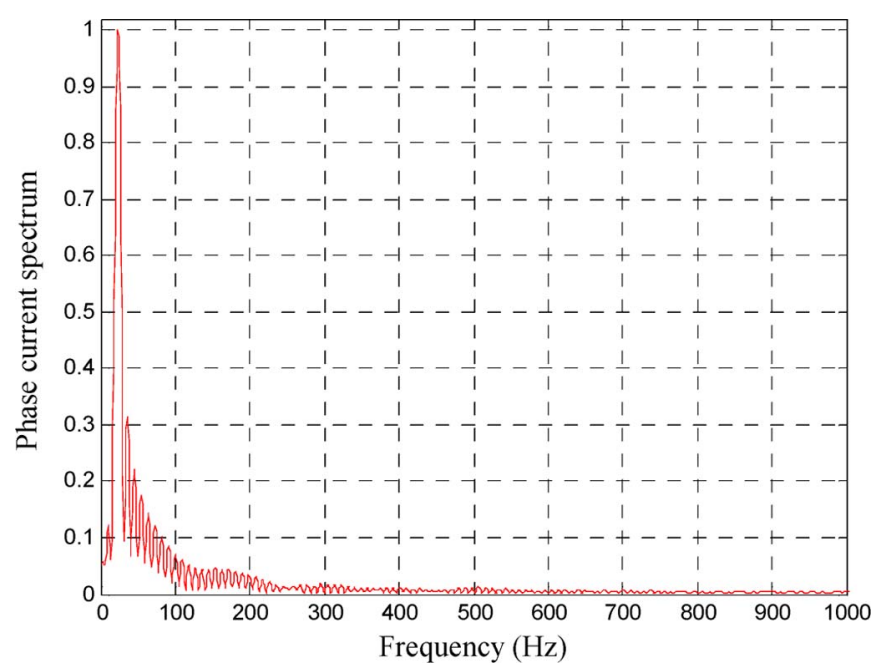

Fig. 14. Seven-level cascaded H-bridge inverter phase current FFT analysis. 


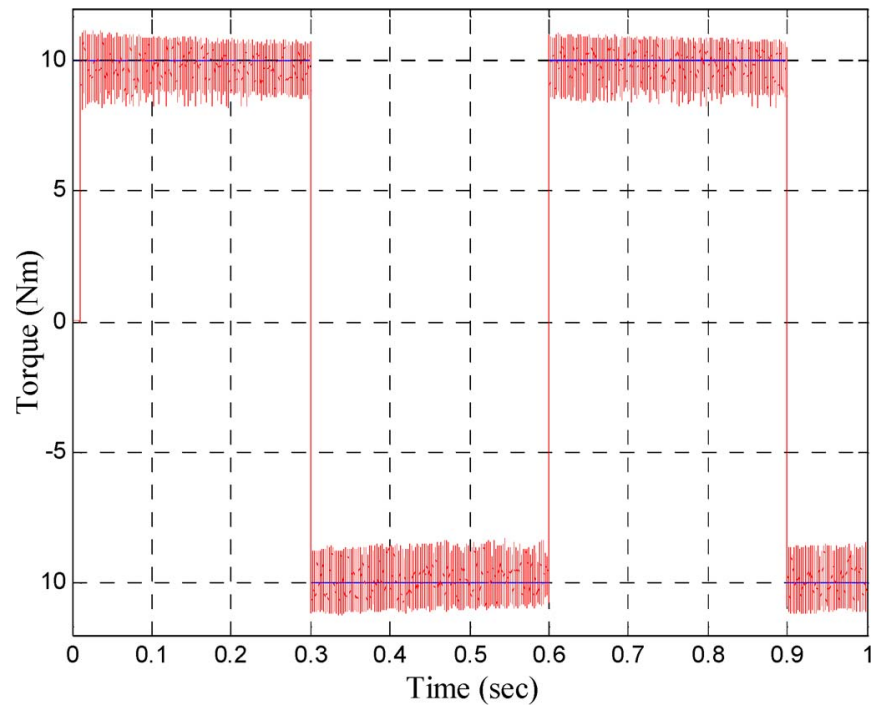

Fig. 15. Two-level cascaded H-bridge inverter estimated torque waveform.

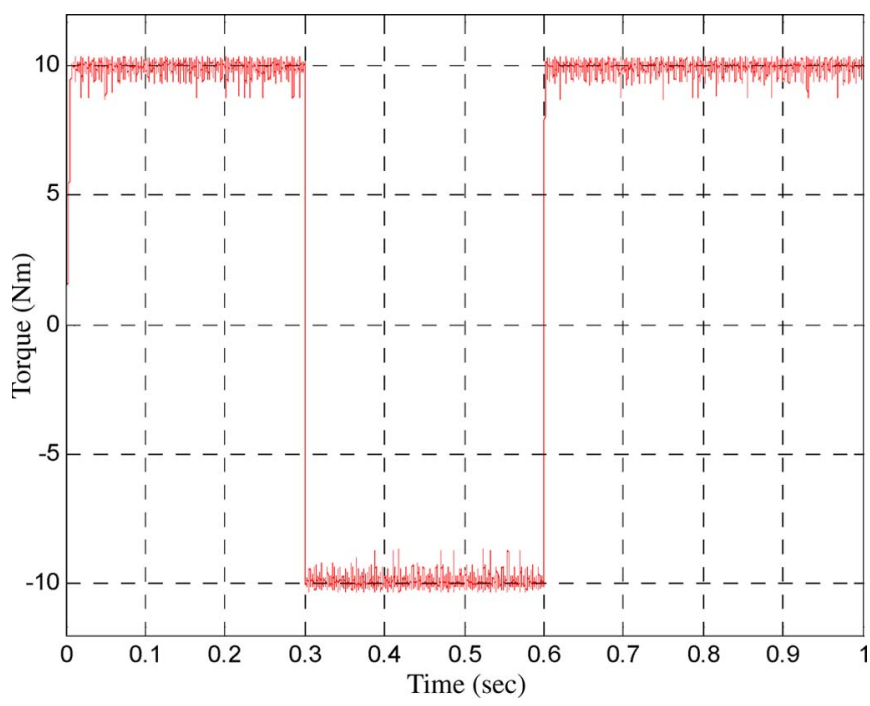

Fig. 16. Five-level cascaded H-bridge inverter estimated torque waveform.

control. This is of course due to the use of the seven-level cascaded H-bridge inverter.

3) The output voltage (Fig. 11) and the induction motor current (Fig. 13) waveforms can be clearly appreciated. They appear nearly sinusoidal, as shown by the FFT analysis (Figs. 12 and 14).

\section{EXPERIMENTAL RESULTS}

For the experimental verification of the proposed control strategy, a three-phase DSP (TMS320LF2407A)-controlled seven-level cascaded H-bridge multilevel DTC inductionmotor-drive system prototype was built and tested (Fig. 17). A 30-A IGBT-based multilevel inverter was used to supply the induction motor. The used induction motor is the same as the one used for simulations.

The control algorithm has been implemented with a $120-\mu$ s cycle. It should be noted, as shown by Fig. 17, that the experimental setup was built to slightly emulate an EV. Unfortunately, it was not possible, at this time, to experimentally use

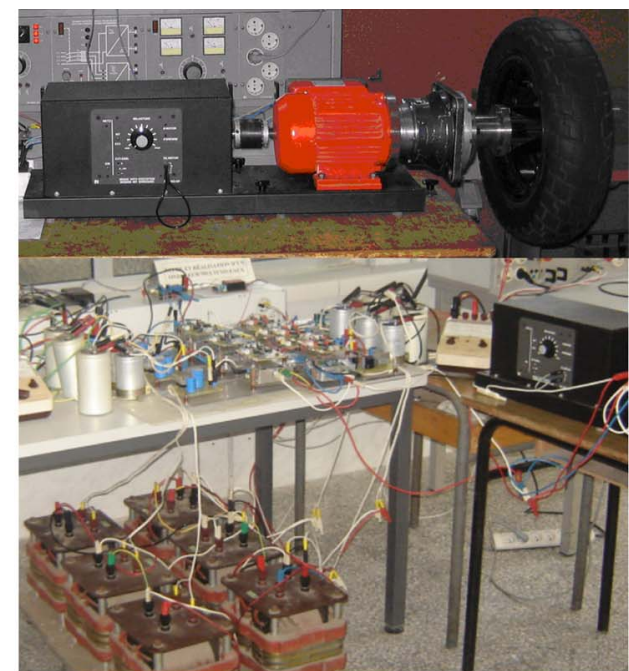

(a)

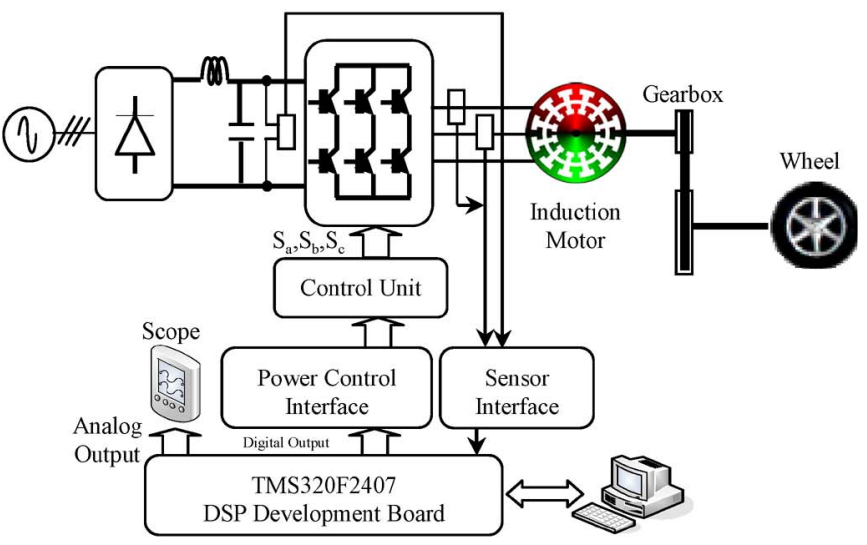

(b)

Fig. 17. Experimental setup. (a) Experimental hardware view. (b) Experimental setup block diagram.

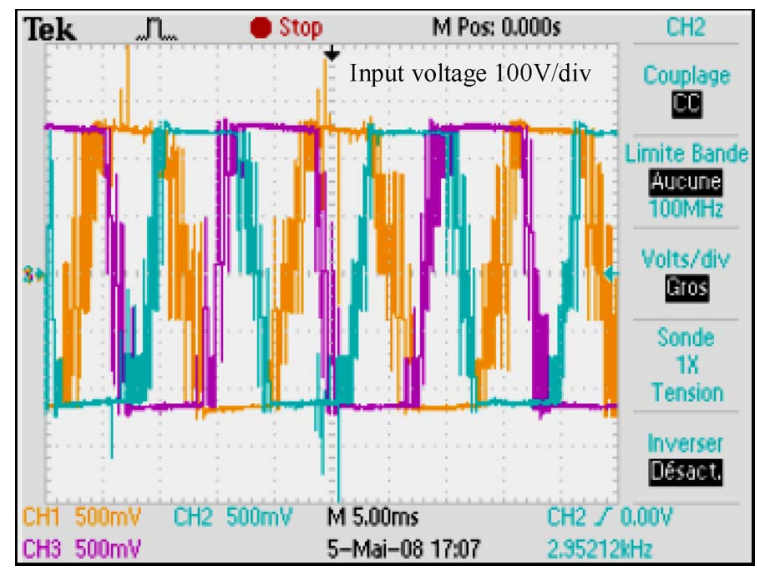

Fig. 18. Multilevel-inverter output voltages during DTC.

a standard test cycle [32]. In our case, the shown tire is just used to generate the induction motor load torque.

Figs. 18-21 show the experimental results of the inverter realized in the laboratory (Fig. 17). In Fig. 18, the stator voltage waveforms captured with an oscilloscope in the starconnected induction motor phases can be seen. The number of voltage levels is increased to seven, achieving a more sinusoidal waveform. The induction motor currents are shown in Fig. 19. 


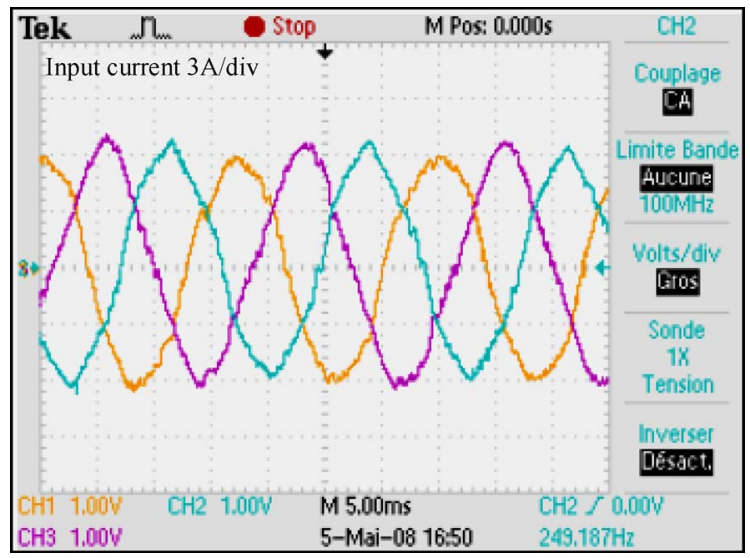

Fig. 19. Output current waveforms.

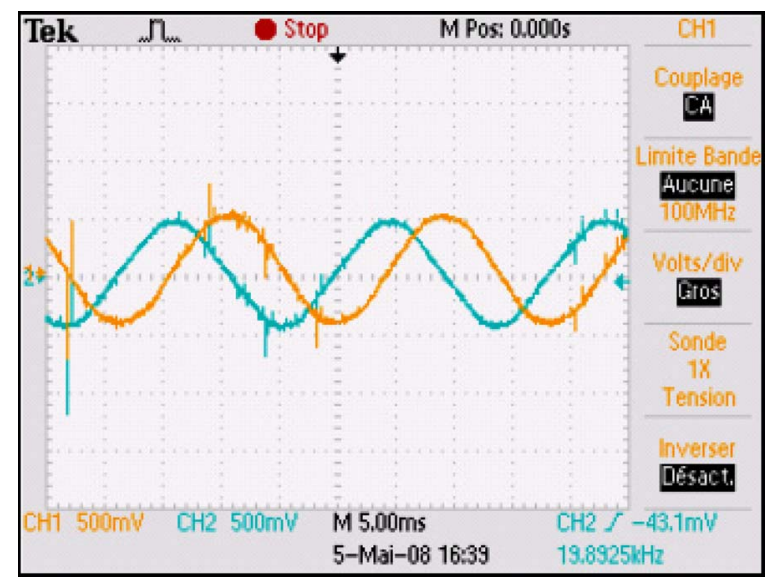

Fig. 20. $\alpha-\beta$ flux component waveforms.

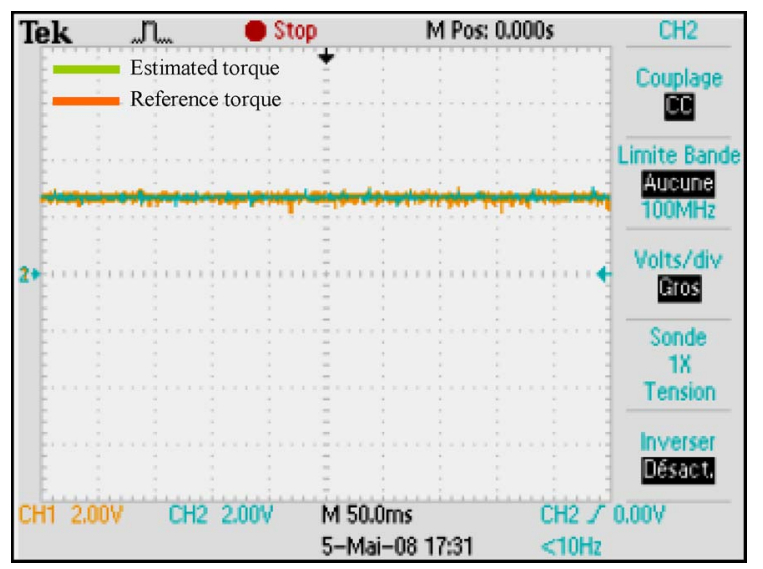

Fig. 21. Reference and estimated torque waveforms.

They appear completely sinusoidal, since the low-pass nature of the load has filtered the high frequency content of the applied voltage. The stator flux, shown in Fig. 20, is measured through the DSP controller analogical exits with constant amplitude imposed by the flux controller. This result confirms the good dynamic performance of the drive. The most important experimental result is that the torque ripple, as shown in Fig. 21, has been almost eliminated in comparison to a two-level traditional DTC [33].

\section{CONCLUSION}

This paper has dealt with a hybrid cascaded H-bridge multilevel motor drive DTC control scheme that has big potential for EVs or HEVs. The main achievements of the proposed control method are significant reduction in the torque ripple, sinusoidal output voltages and currents, lower switching losses, and a high-performance torque and flux regulation. The hybrid multilevel inverter enables a DTC solution for high-power motor drives, not only due to the higher voltage capability provided by multilevel inverters but also mainly due to the reduced switching losses and the improved output voltage quality, which provides a sinusoidal current without an output filter.

\section{APPENDIX \\ RATED DATA OF THE Simulated AND TESTED INDUCTION MOTOR}

$$
\begin{gathered}
1 \mathrm{~kW}, 50 \mathrm{~Hz}, 400 / 230 \mathrm{~V}, 3.4 / 5.9 \mathrm{~A}, 1420 \mathrm{r} / \mathrm{min} \\
R_{s}=4.67 \Omega, R_{r}=8 \Omega, L_{s}=L_{r}=0.347 \mathrm{H}, M=0.366 \mathrm{H} \\
J=0.06 \mathrm{~kg} \cdot \mathrm{m}^{2}, \beta=0.042 \mathrm{~N} \cdot \mathrm{m} \cdot \mathrm{s}
\end{gathered}
$$

\section{REFERENCES}

[1] L. G. Franquelo, J. Rodriguez, J. I. Leon, S. Kouro, R. Portillo, and M. A. M. Prats, "The age of multilevel converters arrives," IEEE Ind. Electron. Mag., vol. 2, no. 2, pp. 28-39, Jun. 2008.

[2] J. Rodriguez, J. S. Lai, and F. Z. Zeng, "Multilevel inverters: A survey of topologies, controls and applications," IEEE Trans. Ind. Electron., vol. 49, no. 4, pp. 724-738, Aug. 2002.

[3] A. Das, K. Sivakumar, R. Ramchand, C. Patel, and K. Gopakumar, "A combination of hexagonal and 12-sided polygonal voltage space vector PWM control for IM drives using cascaded two-level inverters," IEEE Trans. Ind. Electron., vol. 56, no. 5, pp. 1657-1664, May 2009.

[4] X. Yuan and I. Barbi, "Fundamentals of a new diode clamping multilevel inverter," IEEE Trans. Power Electron., vol. 15, no. 4, pp. 711-718, Jul. 2000 .

[5] J. Huang and K. A. Corzine, "Extended operation of flying capacitor multilevel inverters," IEEE Trans. Power Electron., vol. 21, no. 1, pp. 140-147, Jan. 2006.

[6] M. F. Escalante, J. C. Vannier, and A. Arzande, "Flying capacitor multilevel inverters and DTC motor drive applications," IEEE Trans. Ind. Electron., vol. 49, no. 4, pp. 809-815, Aug. 2002.

[7] T. Ishida, K. Matsuse, T. Miyamoto, K. Sasagawa, and L. Huang, "Fundamental characteristics of five-level double converters with adjustable DC voltages for induction motor drives," IEEE Trans. Ind. Electron., vol. 49, no. 4, pp. 775-782, Aug. 2002.

[8] Z. Du, L. M. Tolbert, J. N. Chiasson, and B. Ozpineci, "A cascade multilevel inverter using a single fuel cell DC source," in Proc. IEEE APEC, Dallas, TX, Mar. 2006, vol. 1, pp. 426-430.

[9] J. Liao and M. Ferdowsi, "An improved cascaded H-bridge multilevel inverter controlled by an unbalanced voltage level sigma-delta modulator," in Proc. IEEE VPPC, Harbin, China, Sep. 2008, pp. 1-5.

[10] J. Wang, "Practical design considerations of power electronics in hybrid and fuel cell vehicles," in Proc. IEEE VPPC, Harbin, China, Sep. 2008, pp. 1-6.

[11] S. Lu, K. A. Corzine, and M. Ferdowsi, "A unique ultracapacitor direct integration scheme in multilevel motor drives for large vehicle propulsion," IEEE Trans. Veh. Technol., vol. 56, no. 4, pp. 1506-1515, Jul. 2007.

[12] C. Rech and J. R. Pinheiro, "Hybrid multilevel converters: Unified analysis and design considerations," IEEE Trans. Ind. Electron., vol. 54, no. 2, pp. 1092-1104, Apr. 2007

[13] M. Veenstra and A. Rufer, "Control of a hybrid asymmetric multilevel inverter for competitive medium-voltage industrial drives," IEEE Trans. Ind. Appl., vol. 41, no. 2, pp. 655-664, Mar./Apr. 2005.

[14] P. C. Loh, G. H. Bode, and P.-C. Tan, "Modular hysteresis current control of hybrid multilevel inverters," Proc. Inst. Elect. Eng.-Electr. Power Appl., vol. 152, no. 1, pp. 1-8, Jan. 2005. 
[15] Y. S. Lai and F. S. Shyu, "Topology for hybrid multilevel inverter," Proc. Inst. Elect. Eng.-Electr. Power Appl., vol. 149, no. 6, pp. 449-458, Nov. 2002.

[16] M. A. S. Aneesh, A. Gopinath, and M. R. Baiju, "A simple space vector PWM generation scheme for any general $n$-level inverter," IEEE Trans. Ind. Electron., vol. 56, no. 5, pp. 1649-1656, May 2009.

[17] Y. Liu, H. Hong, and A. Q. Huang, "Real-time calculation of switching angles minimizing THD for multilevel inverters with step modulation," IEEE Trans. Ind. Electron., vol. 56, no. 2, pp. 285-293, Feb. 2009.

[18] G. S. Buja and M. P. Kazmierkowski, "Direct torque control of PWM inverter-fed AC motors-A survey," IEEE Trans. Ind. Electron., vol. 51, no. 4, pp. 744-757, Aug. 2004

[19] D. Casadei, F. Profumo, G. Serra, and A. Tani, "FOC and DTC: Two viable schemes for induction motors torque control," IEEE Trans. Power Electron., vol. 17, no. 5, pp. 779-787, Sep. 2002.

[20] A. Haddoun, M. E. H. Benbouzid, and D. Diallo, "A loss-minimization DTC scheme for EV induction motors," IEEE Trans. Veh. Technol., vol. 56, no. 1, pp. 81-88, Jan. 2007.

[21] J. Faiz, M. B. B. Sharifian, A. Keyhani, and A. B. Proca, "Sensorless direct torque control of induction motors used in electric vehicle," IEEE Trans. Energy Convers., vol. 18, no. 1, pp. 1-10, Mar. 2003.

[22] X. del Toro Garcia, A. Arias, M. G. Jayne, and P. A. Witting, "Direct torque control of induction motors utilizing three-level voltage source inverters," IEEE Trans. Ind. Electron., vol. 55, no. 2, pp. 956-958, Feb. 2008.

[23] J. Rodriguez, J. Pontt, S. Kouro, and P. Correa, "Direct torque control with imposed switching frequency in an 11-level cascaded inverter," IEEE Trans. Ind. Electron., vol. 51, no. 4, pp. 827-833, Aug. 2008.

[24] S. Kouro, R. Bernal, H. Miranda, C. A. Silva, and J. Rodriguez, "Highperformance torque and flux control for multilevel inverter fed induction motors," IEEE Trans. Power Electron., vol. 22, no. 6, pp. 2116-2123, Nov. 2007.

[25] F. Khoucha, S. M. Lagoun, K. Marouani, A. Kheloui, and M. E. H. Benbouzid, "Hybrid cascaded H-bridge multilevel inverter motor drive DTC control for Electric Vehicles," in Proc. ICEM, Vilamoura, Portugal, Sep. 2008, pp. 1-6.

[26] M. Zeraoulia, M. E. H. Benbouzid, and D. Diallo, "Electric motor drive selection issues for HEV propulsion systems: A comparative study," IEEE Trans. Veh. Technol., vol. 55, no. 6, pp. 1756-1764, Nov. 2006

[27] M. Carpita, M. Marchesoni, M. Pellerin, and D. Moser, "Multilevel converter for traction applications: Small-scale prototype tests results," IEEE Trans. Ind. Electron., vol. 55, no. 5, pp. 2203-2212, May 2008.

[28] S. Dieckerhoff, S. Bernet, and D. Krug, "Power loss-oriented evaluation of high voltage IGBTs and multilevel converters in transformerless traction applications," IEEE Trans. Power Electron., vol. 20, no. 6, pp. 1328-1336, Nov. 2005.

[29] Z. Du, L. M. Tolbert, J. N. Chiasson, B. Ozpineci, H. Li, and A. Q. Huang, "Hybrid cascaded H-bridges multilevel motor drive control for electric vehicles," in Proc. IEEE PESC, Jeju, South Korea, Jun. 2006, pp. 1-6.

[30] D. Casadei, G. Serra, A. Stefani, A. Tani, and L. Zarri, "DTC drives for wide speed range applications using a robust flux-weakening algorithm," IEEE Trans. Ind. Electron., vol. 54, no. 5, pp. 2451-2461, Oct. 2007.

[31] V. Ambrozic, M. Bertoluzzo, G. S. Buja, and R. Menis, "An assessment of the inverter switching characteristics in DTC induction motor drives," IEEE Trans. Power Electron., vol. 20, no. 2, pp. 457-465, Mar. 2005.

[32] A. Haddoun, M. E. H. Benbouzid, and D. Diallo, "Modeling, analysis, and neural network control of an EV electrical differential," IEEE Trans. Ind. Electron., vol. 55, no. 6, pp. 2286-2294, Jun. 2008.

[33] F. Khoucha, K. Marouani, A. Haddoun, A. Kheloui, and M. E. H. Benbouzid, "An improved sensorless DTC scheme for EV induction motors," in Proc. IEEE IEMDC, Antalya, Turkey, May 2007, vol. 2, pp. 1159-1164.

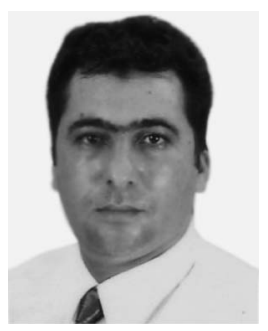

Farid Khoucha was born in Khenchela, Algeria, in 1974. He received the B.Sc. and M.Sc. degrees in electrical engineering from the Polytechnic Military Academy, Algiers, Algeria, in 1998 and 2003, respectively, where he is currently working toward the Ph.D. degree in electric and hybrid vehicle control and power management in collaboration with the University of Brest, Brest, France.

In 2000, he joined the Electrical Engineering Department, Polytechnic Military Academy, as a Teaching Assistant. He is also with the Laboratoire Brestois de Mécanique et des Systèmes (EA 4325), University of Brest, Brest, France.

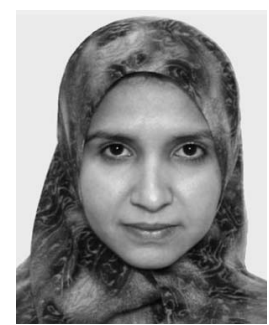

Soumia Mouna Lagoun was born in Djelfa, Algeria, in 1982. She received the B.Sc. in electrical engineering from the University of Djelfa, Djelfa, in 2004 and the M.Sc. degree in electrical engineering from the Polytechnic Military Academy, Algiers, Algeria, in 2008. She is currently working toward the Ph.D. degree in renewable energy systems at the University of Laghouat, Laghouat, Algeria, in collaboration with the University of Brest, Brest, France.

Mrs. Lagoun is currently a Teaching Assistant with the University of Laghouat. She is also with the Laboratoire Brestois de Mécanique et des Systémes (EA 4325), University of Brest. Her current research interests are the control of electrical drives and power electronics.

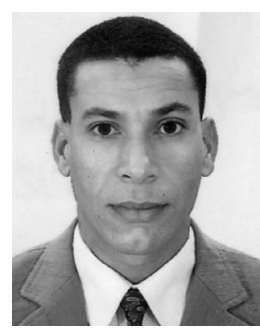

Khoudir Marouani was born in Constantine, Algeria, in 1972. He received the B.Sc. and M.Sc. degrees in electrical engineering from the Polytechnic Military Academy, Algiers, Algeria, in 1996 and 2000 , respectively, where he is currently working toward the Ph.D. degree.

In 2000, he joined the Electrical Engineering Department, Polytechnic Military Academy, as a Teaching Assistant. His main research interests include power electronics, electrical drives and active power filters.

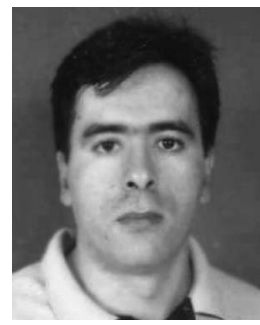

Abdelaziz Kheloui received the M.Sc. degree in electrical engineering from the Ecole Nationale d'Ingénieurs et Techniciens d'Algeria, Algiers, Algeria, in 1990, and the Ph.D. degree in electrical engineering from the National Polytechnic Institute of Lorraine, Nancy, France, in 1994.

Since 1994, he has been with the Electrical Engineering Department, Polytechnic Military Academy, Algiers, where he was an Assistant Professor and is currently an Associate Professor. His current research interests are control of electrical drives and

power electronics.

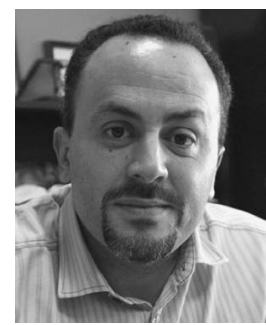

Mohamed El Hachemi Benbouzid (S'92-M'95SM'98) was born in Batna, Algeria, in 1968. He received the B.Sc. degree in electrical engineering from the University of Batna, Batna, Algeria, in 1990, the M.Sc. and Ph.D. degrees in electrical and computer engineering from the National Polytechnic Institute of Grenoble, Grenoble, France, in 1991 and 1994, respectively, and the Habilitation à Diriger des Recherches degree from the University of Picardie "Jules Verne," Amiens, France, in 2000.

After receiving the Ph.D. degree, he joined the Professional Institute of Amiens, University of Picardie "Jules Verne," where he was an Associate Professor of electrical and computer engineering. Since September 2004, he has been with the Institut Universitaire de Technologie of Brest, University of Brest, Brest, France, where he is a Professor of electrical engineering. His main research interests and experience include the analysis, design, and control of electric machines; variable-speed drives for traction and propulsion applications; and fault diagnosis of electric machines.

Prof. Benbouzid is a Senior Member of the IEEE Power Engineering, IEEE Industrial Electronics, IEEE Industry Applications, IEEE Power Electronics, and IEEE Vehicular Technology Societies. He is an Associate Editor of the IEEE TRANSACTIONS ON ENERGY CONVERSION, IEEE TRANSACTIONS ON INDUSTRIAL ELECTRONICS, IEEE TRANSACTIONS ON VEHICULAR TECHNOlogy, and IEEE/ASME TRANSACTIONS ON MECHATRONICS. 